\title{
Holding all the cards? Quality management by cooperatives in a Moroccan dairy value chain
}

\author{
Nicolas Faysse ${ }^{1}$; Cristina Simon ${ }^{2}$ \\ ${ }^{1}$ CIRAD, G-Eau Research Unit, Montpellier, France and \\ Ecole Nationale d'Agriculture de Meknes. \\ ${ }^{2}$ Institute for Higher Education in Tropical Agri-food \\ Industry \& Rural Development, Montpellier, France and \\ Ecole Nationale d'Agriculture de Meknes.
}

This is the post-peer reviewed version of the article with the same title, which has been published in final form in the European Journal of Development Research, at http://www.palgrave-journals.com/ejdr/journal/v27/n1/abs/ejdr201423a.html

\begin{abstract}
Producer organizations are often said to have the potential to help farmers meet the increasing quality requirements of agricultural value chains. However, the external environment may influence producer organizations' room for maneuver in implementing effective quality management. This article assesses the influence of the relations between producer organizations, producers, and other actors of the value chain on the capacity of producer organizations to implement quality management. Our analysis focuses on four Moroccan milk collection cooperatives that started using a milk analyzer with the aim of eliminating cheating by their suppliers. The cooperatives' room for maneuver in improving quality management was limited by the presence of competitors for milk collection and by the agro-industry's lack of transparency in the way its own quality controls were applied. Future studies on how producer organizations can meet the quality challenge should include the strategies of other actors of the value chain in their analyses.
\end{abstract}

Keywords: cooperative; dairy production; free riding; milk analyzer; Morocco; quality management

\section{Introduction}

Agricultural value chains in developing countries are increasingly differentiating products by quality. Quality grades and standards are more and more controlled by the private sector and are becoming progressively more stringent (Henson and Reardon, 2005). This implies increased interdependence between farmers and the other actors of the value chains, not only in terms of measuring the quality of the products, but also in defining the standards to be applied and implementing a payment system based on quality. The capacity of small-scale farmers in developing countries to join (or remain in) value chains that demand higher and higher quality is a topic of growing interest (Humphrey, 2006; Reardon et al, 2009). If small-scale farmers do not succeed in improving quality, they may be excluded from the main value chains. This may lead to a dual system, one involving a high-value 
supply chain based on high-quality requirements that farmers cannot meet, and the other a lower-value sector that survives alongside (Dries and Swinnen, 2004; Simonoskova and Nilsson, 2011). Several academic studies and policy documents published by international institutions point to the role producer organizations can play in helping small-scale farmers improve quality and in finding their place in these evolving value chains (Coulter et al, 1999; World Bank, 2007). Their core argument is that producer organizations can combine coordination with their members and with the other actors of the supply chain (Bijman and Wollni, 2009).

Most studies on producer organizations consider that the key obstacles to improving quality are related to their governance and management capacity. Indeed, when producer organizations collect the farmers' products, the relation between the organizations and their members concerning quality is complex, since farmers are both suppliers of the cooperative, and owners and decision makers. As suppliers, farmers may want the producer organization to accept all their products irrespective of quality, and, if the organization collects and pools farmers' products, they may attempt to 'free ride' on the quality of the products they deliver. As owners and decision makers, members may have diverging interests that can affect the capacity of the cooperative to implement quality management. Some members may disagree with a quality-based payment principle (Cechin et al, 2013a) or prefer to distribute the profits of the organization to increase short-term payments instead of making the collective investments (Cook, 1995) required to improve quality. Even when the principle of a qualitybased payment is accepted, members may disagree on the price grid for different quality (Borgen, 2011). Moreover, implementing quality management systems creates new problems including how to monitor the activities of the staff of the producer organizations (Hviid, 2006).

Several authors analyzed the relation between producer organizations and their external institutional environment. For instance, Bijman and Wollni (2009) and Prowse (2012) pointed to the capacity of producer organizations to 'level the playing field' in negotiations between farmers and agro-industries. The World Bank (2007, p. 156) pointed out that public administrations often interfere in the governance of producer organizations. However, studies of the relations between producer organizations and their members concerning quality generally take the strategies of the other actors of the supply chain as a given and focus on the way producer organizations can meet the quality requirements of these actors (e.g., Narrod et al, 2009). However, these studies do not question the assumption that cooperatives, by and large, hold all the cards needed to improve quality management, provided the administration respects their autonomy. This corresponds to a wider trend in development studies to consider producer organizations as a major locus of both problems related to agricultural development, and solutions to these problems ( $\mathrm{Li}, 2011)$. Policy recommendations based on such analyses often suggest that to improve quality in agricultural value chains involving producer organizations, support should mainly focus on the internal management of these organizations. However, few studies have focused on how producer organizations jointly manage their relations with farmers and with the other actors of the value chain concerning quality management, and how these relations influence the producer organizations' room for maneuver in implementing quality management.

This article assesses the way the relations between producer organizations, producers, and other actors of the value chain influence the capacity of producer organizations to implement quality management. The case study was a dairy value chain in Morocco. A large share of the milk produced in Morocco is collected by cooperatives, which then deliver it to dairy processing companies. Previously, these cooperatives did not have the technical equipment to measure the fat content of the milk delivered to the cooperative by individual farmers. This led to free-rider behavior with farmers skimming the milk before delivering it to the cooperative, resulting in lower quality milk in cooperative tanks and in penalties imposed by the dairy industry. Automatic milk analyzers were recently introduced in Morocco, providing an opportunity for cooperatives to improve quality management. We assess the quality management systems of four milk collection cooperatives based on the use of automatic analyzers. We use the quality management reform to analyze the influence of the relationship between cooperatives, farmers, and other actors of the value chain on the ability of milk cooperatives to improve quality management. 


\section{Links between quality management and relations among actors of the value chain}

In the following subsection, we analyze how producer organizations take their relations with their members into account in the design of quality management systems. In the second subsection, we present the main findings of studies on the influence of actors of the value chain on quality management by the farmers and by the cooperatives.

\section{Relations between producer organizations and their members}

In some cases, producer organizations involved in marketing the products of their members do not pool the products. When these organizations are able to pay each member according to the quality of his/her products, they are in a good position to improve the quality of the products concerned (Kaganzi et al, 2009). However, in many cases, producer organizations - usually cooperatives - pool their products before marketing them. In the past, most cooperatives accepted their members' total production; and the price they paid the farmer was not based on quality. The increasing demand for quality means cooperatives are obliged to introduce a quality management system, implying that products that do not meet quality standards can be refused, and often that payment has to be based on quality criteria (Nilsson, 1998). If cooperatives do not introduce quality management systems, they may have to deal with problems of adverse selection and moral hazard, leading to products of lower quality being delivered to the cooperative by the farmers (Fulton and Sanderson, 2002).

Cooperatives generally have some kind of system to judge the quality of the products delivered by individual farmers. Such quality management systems have two sets of rules: (i) a system of classification and payment that defines quality, and the relation between quality and the price paid to farmers; (ii) rules that define how quality is measured and how quality controls are implemented. This is the case in sugar value chains (Boland and Marsh, 2006) and in coffee value chains (Chaddad and Boland, 2009). Producer organizations' quality management systems often take differences in the farm characteristics and/or the strategies of their members into account. In India, thousands of cooperatives collect both cows milk and buffalo milk. Buffalo milk has a much higher fat content than cows milk. Milk analyzers measure the fat content of all the milk delivered to the cooperatives. Farmers are paid daily according to the volume and fat content of the milk (which may be a mix of cows and buffalo milk) they delivered to the cooperative (Bowonder et al, 2005).

To function in a sustainable way, a quality management system needs to pass a series of tests. Here, we further elaborate the typology of technical, economic and social tests proposed by Touzard (2010). A major technical test corresponds to whether the quality measurement system evaluates all quality criteria that have a bearing on the prices paid to the cooperative by downstream actors in the supply chain. Another technical test amounts to whether the machines used to measure quality provide reliable measurements of quality and do not break down often. The quality management system needs to pass economic tests at cooperative and farm level. At cooperative level, the economic benefits of the quality management system must be higher than the cost of implementing quality control. The increase in sales of the product by the cooperative thanks to improved quality must be higher than the increase in the price to be paid by the cooperative to farmers if the cooperative sets up a payment system based on quality. At farm level, the prices paid by the cooperative to farmers for improved quality must be higher than the cost of obtaining a higher quality product from the farmers (put in another way, the price paid by the cooperative for low quality products should be penalizing for farmers). The main social test corresponds to whether farmers accept the legitimacy of the quality management system. The design of a quality management system does not only depend on whether farmers believe they will benefit economically from the new system. The set of values shared by farmers formsan (often implicit) convention, which provides legitimacy and defines the general orientation of the quality management system (Touzard et al, 2001). In particular, a long-term relationship between the cooperative and its members can be a major asset in encouraging the farmers to improve the quality of their products (Cechin et al, 2013b). Another social test amounts to whether farmers believe that the selection of farmers who are subject to quality controls is impartial. 
Producer organizations may face technical difficulties in measuring the quality of their members' products. Lack of equipment for measuring quality is a major constraint. Many milk collection cooperatives in East Africa have measurement tools that can only measure milk density and freshness. These cooperatives can only refuse the milk that does not meet very simple quality requirements and farmers are not paid based on the quality of their milk (Francesconi, 2009; Nyoro and Ngugi, 2007). When there is no equipment to measure quality, farmers can 'free ride' on the quality of their products. Free riding has been identified in wine production (Pennerstorfer and Weiss, 2012), coffee (Mahdi, 2012) and dairy production (Gorton et al, 2006). Non-compliance with quality standards may lead to penalties that are imposed on the whole producer organization by buyers (Narrod et al, 2009).

The purchase of equipment to measure quality can help limit free-riding behavior. In the dairy sector in Europe at the end of the $19^{\text {th }}$ century, cooperatives started using machines to check milk quality, since some farmers adulterated the milk by adding water or removing fat. These cooperatives introduced by-laws to punish cheaters and soon started paying the farmers according to milk quality (Henriksen and Hviid, 2004). In other cases, it may be too costly to measure the quality of the product. To circumvent the difficulty of undertaking detailed assessment of the characteristics of wine grapes, French, Italian and German wine cooperatives defined quality standards that include not only the characteristics of the grape but also farming practices. The members of these cooperatives choose which quality standards they wish to apply and are checked accordingly (Capitello and Agnoli, 2009; Hanf and Schweickert, 2012; Touzard, 2010).

\section{Influence of actors of the value chain on quality management by farmers and cooperatives}

Here we present key results of studies that assessed the relation between farmers and agro-industries with regards to quality. Quality assessment and payment are playing an increasingly important role in the relation between farmers and agro-industries (Bogetoft and Olesen, 2002; Henson et al, 2005). The agro-industries' aim to improve quality is resulting in increasingly 'buyer driven' value chains, in which agro-industries play a leading role in defining and enforcing the complex quality standards that govern their relation with farmers (Ponte and Gibbon, 2005). When quality measurement systems become too complex, farmers often do not have sufficient information to challenge the grading system laid down by the lead firm (Prowse, 2012). This lack of transparency may be intentional, as it could prevent farmers from checking they receive adequate remuneration (Bijman, 2008). When agroindustries are in a position of monopsony (which is often the case), farmers have limited power to challenge the quality management systems designed and implemented by agro-industries (Singh, 2002; Wu, 2006).

The capacity of producer organizations to improve quality may be affected by the presence and strategies of actors situated "vertically" (in particular agro-industries) and actors situated "horizontally" (other actors buying the same products from members of the producer organizations). In the wine sector in Europe, there are many cases where farmers sell their high-quality grapes to private buyers and their lower quality grapes to the cooperative (Theodorakopoulou and Iliopoulos, 2012). Failure by the cooperatives to control quality may lead to a spiral of decreasing quality at cooperative level, since farmers who produce high-quality products may decide to leave the cooperative and start delivering to private firms (Mather and Greenberg, 2003). Implementing quality management is especially difficult in situations where the cooperatives need to collect large quantities of products in order to cover their operating costs. Berdegué (2001, p. 170) reported an attempt by a milk collection cooperative to stop accepting deliveries from farmers whose milk was of low quality. This attempt failed because the farmers were able to deliver their milk elsewhere. If the cooperative had stopped accepting low quality milk, it would not have had enough milk to cover its operating costs. However, this does not necessarily imply that cooperatives are in a weak position when they want to ensure members deliver quality products in the presence of competitors. At the beginning of the $20^{\text {th }}$ century, dairy cooperatives in Ireland faced the problem of farmers skimming their milk before delivering it to the cooperative. These cooperatives solved the problem more effectively than private creameries because, once they had acquired the machines they needed to measure milk quality, they included in their by-laws the requirement that farmers must deliver their entire production of 
unadulterated milk to the cooperative. Farmers found cheating had to pay a fine. Farmers who did not agree with the new by-laws and wanted to leave the cooperative, would lose their share of the cooperative's assets (Rourke, 2007).

\section{Dairy chains in Morocco}

Moroccan dairy chains are based on the milk produced by approximately 790,000 farms and organized in two main ways. The first way involves milk processing in large-scale plants. The main operator in this chain is a private company, Centrale Laitière (Central Dairy in French), which processes $60 \%$ of the milk transiting in this way. The second way involves informal circuits, whereby milk is sold directly to consumers or processed by small-scale dairies (Sraïri, 2011). In the first way, a few largescale dairy farms have their own tanks and supply the dairy industry directly, but the vast majority of dairy farmers deliver their milk to a collection center. There are around 1,000 milk collection centers in Morocco, and these handle the bulk of milk processed by dairy firms (Sraïri, 2011). The great majority of these centers are cooperatives. These cooperatives only collect milk but do not process it themselves.

Members of a milk collection cooperative deliver the milk to the cooperative collection center once or twice a day. At the center, the milk is collected by an employee, who is usually the only permanent employee paid by the cooperative. Some cooperatives use a pick-up truck to collect milk from farmers located a long distance from their collection centers. The dairy processing company collects the milk from the cooperatives once a day; their drivers remove a sample of the milk in the cooperative tanks, which is later analyzed by the dairy firm. In the 1970s, the Moroccan administration played a key role in the development of dairy chains, but now only intervenes in the dairy sector at the macro level and does not interfere in the relations between cooperatives and industries.

Centrale Laitière pays milk collection cooperatives at two-weekly intervals based on the quantity and quality of the milk collected. Before 2011, Centrale Laitière paid a baseline price that was subject to bonuses and penalties based on milk fat and protein content. In 2011, Centrale Laitière decided to prioritize high-quality milk and started using a new classification system for milk quality and a related payment system that increased the gap between the prices paid for higher and lower quality milk. Four classes of milk quality were defined, mainly based on the absence of antibiotics and added water, milk stability, and the concentration of non-fat milk solids. Each quality class has its own baseline price, which changes twice a year with a higher price paid during the low lactation period (August to January) than in the high lactation period (February to July). In 2012, the baseline price of the different quality classes ranged from 3 to 3.5 Moroccan Dirham (DH) per liter $^{1}$ (between 33 and 38 eurocents) in the high lactation period. Once a quality class has been assigned to a batch of milk, the baseline price is modified by bonuses and penalties based on fat and protein content. Milk collection cooperatives pay the same price to all farmers irrespective of the quality of the milk delivered by each individual farmer (Sraïri et al, 2009).

There are different reasons for the variation in fat content, including the breed of cattle, the type of cattle feed, or the stage of lactation. In the present study, the members of cooperatives we interviewed and staff from Centrale Laitière believed that skimming was the main cause of such variation. Farmers may skim the milk by keeping it on the farm for some hours and removing the cream before delivering the milk to the cooperative. They can sell butter made from the cream in local markets or keep it for domestic use. Skimming is a major problem for cooperatives. In the past, the cooperative did not have the technical equipment to measure the fat content of the milk they received. Cooperatives only checked milk acidity and density (to make sure milk had not been watered down). Skimming led to low quality milk in cooperative tanks. The resulting penalties imposed by the dairy processing companies triggered endless conflicts among members of the cooperatives and destabilized the management of the cooperatives. As a solution to this problem, some cooperatives require farmers to deliver milk twice a day. This can limit (but not completely prevent) farmers from skimming their milk. 
Recently, low-cost and easy-to-use Rapid Automatic Milk Analyzers (RAMAs, Draaiyer et al, 2009) became available in Morocco. In 2010, some cooperatives purchased RAMAs on their own initiative to check the quality of the milk supplied by their members. The first model to be purchased was often Ekomilk$^{2}$. Later, Centrale Laitière also started promoting RAMAs and helped the cooperatives to purchase them. After testing different RAMA models in 2011, Centrale Laitière selected the Lactoscan SA (Milktronic Ltd, 2013) for its precision and stability. This RAMA measures the fat, water, protein, and non-fat solids in a sample of milk in approximately 50 seconds. In 2012, this model cost around 15,000 DH (about 1,360 Euros) in Morocco. In April 2012, Centrale Laitière launched a plan to promote the installation of Lactoscan analyzers in dairy cooperatives and investor-owned milk collection centers in the Casablanca region as well as in the major dairy production regions of Morocco where Centrale Laitière collects milk.

\section{Case studies and data collection}

The region of Casablanca was chosen for this study because the first RAMAs introduced in Morocco were used in this region and in the neighboring El Jadida region. Four cooperatives were selected for the study and are referred to as C1, C2, C3 and C4. These cooperatives were chosen based on the following criteria: the date of installation of the analyzer, the use of a pick-up truck to collect milk, and the presence of competitors for milk collection (Table 1). Figure 1 shows the main actors of the supply chains based on the milk sold by farmers who were members of one of the cooperatives in this study.

Only members of C2 had no alternative option for milk delivery, except for one small-scale individual collector who collected very small quantities. Members of C1 could deliver to small-scale dairies located in a town close to the cooperative. Members of C3 and C4 could sell to individual collectors, who fetched milk from the farms in a pick-up truck. These collectors paid roughly the same price as the two cooperatives, and most of them delivered the milk they collected to Centrale Laitière. Members of C1, C3 and C4 generally preferred to deliver to the cooperatives because the collectors and local dairies do not always purchase milk in high lactation periods.

Centrale Laitière was the only large-scale milk processing firm that collected milk in the vicinity of C2, C3 and C4. Another dairy firm collected milk in the region of C1, with almost the same conditions and prices as Centrale Laitière. There was no written contract between Centrale Laitière and the four cooperatives studied here. Most cooperatives in the Casablanca region (including the four in this study) collected milk, helped their members purchase heifers, and purchased cattle feed. All four cooperatives belonged to local federations, but these federations negotiated only rarely with Centrale Laitière on behalf of the cooperatives.

All four cooperatives had been subject to penalties (ranging from 270 Euros and 470 Euros per twoweek period, depending on the cooperative), for low milk quality before installing the RAMA. Cooperatives C1 and C2 had already used their RAMA for more than one year at the time of the study. The RAMA had been installed in cooperatives C3 and C4 only a month before the first interviews were conducted. This made it difficult to obtain a stable description of quality management, as C3 and C4 management committees frequently changed the rules for quality control and payment. However, it facilitated the study of the way these cooperatives designed and modified their quality management systems.

The main field work was conducted from April to July 2012. Data on prices paid by Centrale Laitière to cooperatives were collected up to October 2012, with a follow-up in May 2013. In each of the four cooperatives, we met members of the management committee several times (at least twice in the case of the main leader of each cooperative). Interviews with these management committee members focused first on the organization and governance of the cooperative and its relations with Centrale Laitière. Next, the interviews dealt with quality management: who had the idea of acquiring a RAMA, changes in the quality management system after the RAMA was installed, and any impacts on prices paid by Centrale Laitière. Employees of each cooperative were interviewed about the daily implementation of quality control. Eight farmers were interviewed in each cooperative about their 
milk delivery practices and their understanding and acceptance of the cooperative's quality management system. Observations were also made at the collection centers during the milk reception periods. Staff from Centrale Laitière was interviewed six times. These interviews concerned the agroindustry strategies vis-à-vis the implementation of the RAMAs, the specific case of each of the four cooperatives, and preliminary results of the study.

Table 1: Main characteristics of the four milk collection cooperatives

\begin{tabular}{|c|c|c|c|c|}
\hline Cooperatives & $C 1$ & $C 2$ & C3 & C4 \\
\hline Year cooperative was created & 2003 & 2001 & 1977 & 1983 \\
\hline First RAMA installed & 2011 & 2010 & April 2012 & April 2012 \\
\hline $\begin{array}{l}\text { Use of a pick-up truck for milk } \\
\text { collection }\end{array}$ & No & No & Yes & No \\
\hline Number of collection centers & 1 & 3 & 1 & 1 \\
\hline Number of farmers delivering milk & 80 & 166 & 82 & 160 \\
\hline $\begin{array}{l}\text { Quantity of milk collected during the } \\
\text { first } 2 \text { weeks in April } 2012 \text { (liters) }\end{array}$ & 30,000 & 54,300 & 28,500 & 68,200 \\
\hline
\end{tabular}



Figure 1: Main actors of the supply chains of milk sold by farmers belonging to the 4 cooperatives studied here.

\section{Results}

\section{The new quality management systems based on the use of milk analyzers}

In 2011, after having obtained the agreement of the members of the cooperative during a general assembly, the president of C1 cooperative purchased a RAMA. In their interviews, the farmers of C1 cooperative explained that the RAMA was accepted because any farmer who opposed buying one during the general assembly would risk being considered a cheat. The president decided on the 
minimum acceptable fat content for milk. The president performed the analyses himself; one reason being that many farmers did not trust the cooperative employee. The penalties imposed by Centrale Laitière stopped during this period but farmers were not paid according to milk quality. Moreover, the controls were very strict and the president was very blunt, which led to tensions among members of the cooperative. Many farmers refused the validity of the results of the RAMA analyses or argued that the method of selecting which farmers would be checked was not fair. In the general assembly held at the end of 2011, the cooperative bank account was shown to have an unusually large balance $(80,000$ DH, about 7,270 Euros), thanks to bonuses paid by Centrale Laitière for good quality. This sum was distributed among the members of the cooperative. However, the president was severely criticized for the conflicts that had arisen and stepped down. The following president's priority was to limit conflict. He used the RAMA much less frequently and preferred to have the farmers deliver milk twice a day, instead of once. At the beginning of 2012, the RAMA broke down and was sent to Centrale Laitière for repair, but the management committee of C1 made no effort to get it back. Penalties for low milk quality started again after the RAMA broke down. In May 2013, the RAMA was still not in use.

Cooperative C2 had three collection centers. The cooperative was run by its president, and members had little control over his system of management. In 2010, the president purchased a RAMA, and two more in 2011. The RAMAs were used to refuse milk that did not meet the quality criteria laid down by the president regarding fat content, non-fat milk solids, and proteins. Farmers were not paid more if they delivered good quality milk, but the members of the cooperative did not protest. Firstly, many farmers gave more importance to meat than dairy. Secondly, farmers had very little opportunity to deliver milk elsewhere. Thirdly, the distance between collection centers made it difficult for members to meet and collectively ask the president to account for his actions. In May 2013, the quality management system was still being run in a similar way.

In March 2012, the staff of Centrale Laitière held a meeting to promote the use of RAMAs and sold a RAMA to cooperatives C3 and C4. The C3 employee was also the cooperative treasurer. Once the RAMA was installed, checks were made of the milk delivered by farmers to the collection center of C3 and that of farmers who delivered their milk to the pick-up truck. The driver of the pick-up took samples of the milk he collected during his round. These samples were later analyzed using the RAMA at the cooperative collection center. The management committee of C3 paid for the milk based on quality, but payments changed every two weeks depending on the payment received from Centrale Laitière and the cooperative's operating costs. In the first two weeks of May 2012, milk whose fat content was below a minimum threshold was refused, and three different prices were set based on fat content above this value. In May 2013, quality management had been simplified. The RAMA was used only to check that milk met minimum fat and protein content requirements, and was not diluted with water. On ten days during the two-week period, the RAMA was used to check the milk from farmers who delivered once a day, including that of farmers who delivered to the pick-up truck. Farmers who delivered milk twice a day were only rarely checked, because their milk had been checked many times and shown to be of good quality. Cooperative C3 paid the same baseline price to all its members. However, when Centrale Laitière imposed penalties due to low quality, the penalties were paid only by members who delivered once a day.

The main employee of C4 was also its president. When the RAMA was installed, the president insisted that milk should be delivered twice a day. From the outset, the management committee of C3 defined two quality classes depending on fat content and paid a different price for each class. In May 2013, the president routinely made three surprise checks in each two-week period, in such a way that all farmers would be checked at least once every two weeks. The prices of the two classes were calculated every two weeks based on the result of these checks and on the payment received from Centrale Laitière. In cooperatives C2, C3 and C4, the Lactoscan analyzer proved to be relatively robust. Centrale Laitière organized the maintenance of the analyzers and repaired those that broke down. 


\section{Cooperatives' handling of outward relations}

Centrale Laitière's payment system was complex and was based on more quality criteria than those measured by the RAMA (e.g., presence of antibiotics). None of cooperative members and staff knew the values of the quality criteria that Centrale Laitière used to define the quality class of a batch of milk. The form provided by Centrale Laitière to the cooperatives every two weeks reported the quality class of the milk contained in all the cooperative tanks each day for the preceding two weeks, and general penalties or bonuses related to fat content for the whole two-week period. However, no explanation was given about the criteria that had led to a high or low quality classification in the daily assessment of milk quality.

The cooperatives that paid their members based on milk quality were faced with a dilemma. One option was to calculate the price to be paid to farmers for each quality class every two weeks, after how much the cooperative received from Centrale Laitière was known. Cooperatives C3 and C4 originally chose this option, but it led to an unclear and unstable system of payment to farmers. Another option was to define quality criteria and prices paid to farmers that would not change for several months, to give farmers clear incentives to deliver milk that had not been skimmed. However, this would cause problems if Centrale Laitière paid less than the amount that the cooperative had expected to receive, due to low values for criteria that were not measured with the RAMA or because of a difference between the quality measurement made by the cooperative and that made by Centrale Laitière. A cooperative in the Casablanca region (not one of the four studied here) chose this option and faced this very problem. One consequence of the lack of information concerning the quality measurements made by Centrale Laitière was that the management committees of the four cooperatives in our study did not know exactly what they aimed to achieve with the new quality management system, beyond increasing the income received from Centrale Laitière.

The cooperatives' external environment led to other difficulties in improving quality management. As the farmers in the four cooperatives pointed out, milk quality could be altered after collection. For instance, truck drivers could alter the samples and the milk they collected by adding water. This further undermined the confidence the farmers had in Centrale Laitière's quality measurements. Members of the management committees of C3 and C4 cooperatives complained that many of the collectors who competed with their cooperatives for milk collection also delivered milk to Centrale Laitière. The treasurer of C3 insisted that Centrale Laitière stop accepting milk from these collectors if it was genuinely willing to work with the cooperatives to improve quality. However, Centrale Laitière did not acknowledge these complaints.

\section{Cooperatives' handling of inward relations}

In their relation with farmers, cooperatives C1, C3 and C4 had to design the quality management system based on the use of the RAMA in such a way that farmers would accept it as legitimate and fair, and consider it economically advantageous to deliver milk that had not been skimmed. Interviewed farmers (excluding members of the management committee) generally had a similar understanding and acceptance of the new quality management systems in each cooperative. They understood the purpose of the RAMA and the fat value appearing on the RAMA screen. Concerning the legitimacy of the system, members of C3 and C4 considered that the introduction of the RAMA was indispensable since Centrale Laitière had called for improved quality. By contrast, members of C1 considered that improving quality was an initiative of the former president. They acknowledged that the RAMA made it possible to improve the performance of the cooperative, but also considered that the conflicts it caused outweighed the advantages.

On the subject of the fairness of the system, any rules had to leave cooperative employees ample room for maneuver in the choice of who should be checked, since the checks were unannounced. Members' acceptance of the fairness of the checks thus depended to a great extent on whether they believed the cooperative employee was honest. Members of C3 and C4 held the employees of their cooperatives in high esteem, whereas members of C1 did not trust the employee and this was one of the reasons why the RAMA was used much less after the departure of the former president in 2011. 
Finally, most members of C3 and C4 we interviewed were prepared to supply the cooperative with milk that had not been skimmed if they obtained a much higher price. However, what the farmers would gain by delivering full cream milk was not clear. First, the constantly changing price of milk made it difficult for members of $\mathrm{C} 4$ to calculate how much they would gain by delivering milk that had not been skimmed. Second, for famers belonging to C3 and C4 cooperatives, selling butter on the market and delivering skimmed milk to the cooperative produced about the same income as delivering full cream milk to the cooperative. The frequent changes in the system of payment, as well as lack of support from animal science technicians, also explained why C4 farmers made no attempt to improve milk quality by modifying their breeding practices.

\section{Impacts of the new quality management system}

Figure 1 shows variations in bonuses and penalties related to fat content paid by Centrale Laitière to cooperatives C2, C3 and C4 from January 2011 to October 2012. No data was obtained from C1, which stopped using the RAMA at the beginning of 2012. During the study period, leaving aside the biannual change in baseline prices, fat content was by far the most important cause of fluctuations in milk prices paid by Centrale Laitière to cooperatives. The values in Figure 2 do not necessarily correspond to the actual fat content of the milk in the cooperative tanks, because the quality of the milk could have been altered during transport from the cooperative to the dairy firm or due to faulty handling of the milk analyzer used by Centrale Laitière. Despite these uncertainties, interviews with leaders of the four cooperatives and staff of Centrale Laitière gave similar explanations for the data shown in Figure 2.

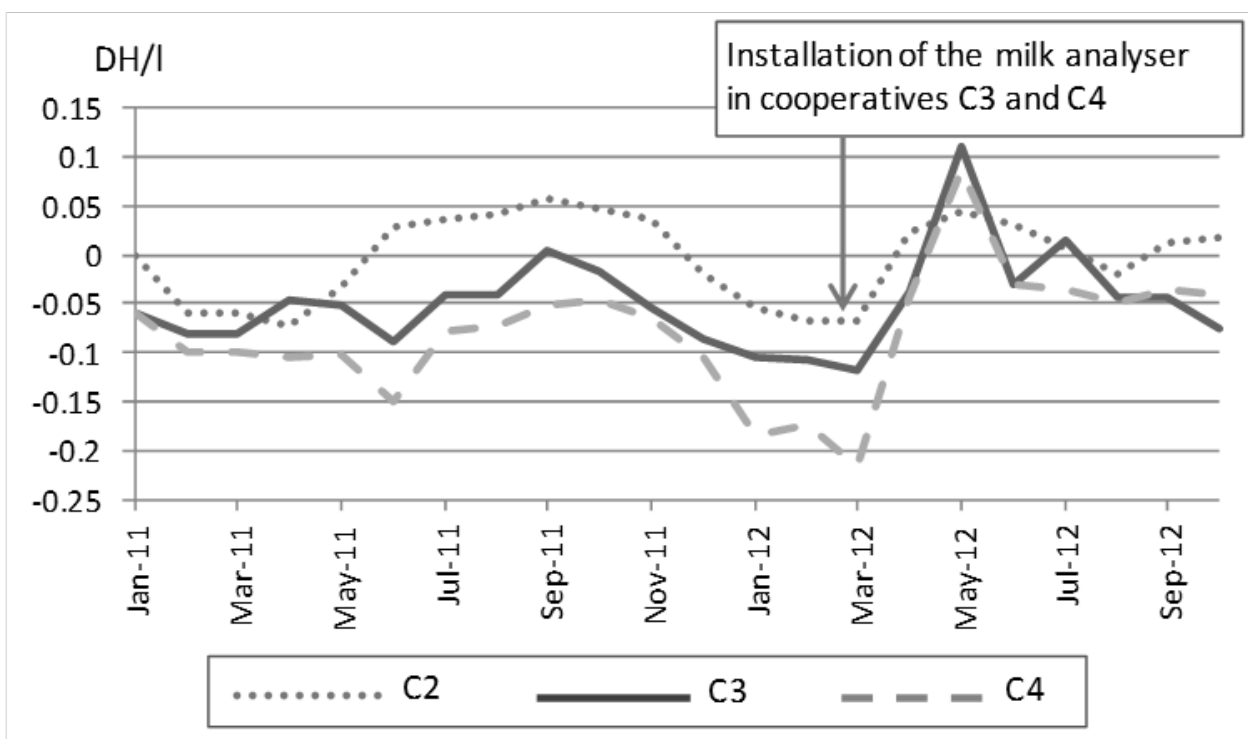

Figure 2: Variations in bonuses and penalties related to fat content paid by Centrale Laitière to the cooperatives.

The installation of the RAMA in cooperatives C3 and C4 in March 2012 led to substantial increases in payments from Centrale Laitière from May to July 2012. However, from July to September 2012, these bonuses progressively decreased. The 2011-2012 winter period was dry. From August 2012 onwards, farms began to run out of fodder and the price of straw and cow feed increased sharply. Cows were consequently fed less and the volume of milk collected by cooperatives decreased. The management committees of C3 and C4 worried that the decrease would make it difficult to cover the operating costs of the cooperatives, such as the employees' salaries. These committees thought they would not be able to put pressure on farmers who were reluctant to deliver milk that had not been skimmed because they could easily sell their milk to independent collectors. They consequently decided to apply less strict quality control. Cooperative C2 was able to continue to apply strict quality 
standards because there was less competition for milk collection. The reduction in milk quality in the fall of 2012 was thus less severe in this cooperative.

The management committees of the cooperatives, the farmers, and Centrale Laitière staff assessed the impacts of the changes in the quality management operated by the cooperatives differently. The management committees of $\mathrm{C} 2, \mathrm{C} 3$ and $\mathrm{C} 4$ considered that the use of the RAMAs improved milk quality and increased the payment received from Centrale Laitière. According to the president of C4, the use of the RAMA reduced penalties from 130,000 DH in 2011 to 80,000 DH in 2012. However, the committees of C3 and C4 said that the increase was much lower than the promising first results in summer 2012. Farmers who delivered to cooperatives C1, C3 and C4 saw little advantage in the new quality management system, and farmers who delivered to C2 saw none. According to a member of staff of Centrale Laitière, the introduction of the RAMAs at the scale of the region of Casablanca was more successful, since, in April 2013, 62 out of the 67 RAMAs distributed in this region were still in working order and the use of RAMAs had enabled an increase in the average fat content of the milk collected by Centrale Laitière in the region by $2 \mathrm{~g} / \mathrm{l}$.

\section{Discussion}

\section{Influence of outward actors on whether the new quality management systems passed the tests}

The four cooperatives attempted to move from a situation in which farmers skimmed their milk to get extra income from selling butter, meaning the milk delivered to the cooperative was of low quality and the purchase price paid to farmers was consequently also low, to a situation in which the farmers refrain from skimming the milk and are paid more by the cooperative for delivering good quality milk. This meant thatthe quality management systems of cooperatives C1, C3 and C4 had to pass technical, economic and social tests. Since C2 was run like a private business, its quality management system only needed to pass the technical and economic tests.

The social tests were important in cooperatives C1, C3 and C4, since power was well shared between the farmers and the cooperatives (because the farmers were also decision makers and because of the presence of competitors for milk collection). These tests were successful in the case of C3 and C4, but unsuccessful in the case of $\mathrm{C} 1$. The influence of outward actors on the results of social tests was limited. By contrast, the results of the technical and economic tests were highly influenced by external actors. Centrale Laitière had a positive influence on the maintenance of the RAMAs, but did not attempt to match its quality grid to the criteria the cooperatives were able to measure with the RAMAs. With regards the economic tests, Centrale Laitière's lack of transparency in its payment did not help cooperative design and monitor quality-based payment systems. Centrale Laitière also had an indirect negative influence since by accepting milk from individual collectors, it increased the latter's capacity to collect milk, and consequently weakened the capacity of the cooperatives to improve quality management.

Overall, the results of the new quality management systems were limited. Due to their limited success in improving milk quality, milk collection cooperatives risk being identified as the "weak link" in the dairy chain. Members of Centrale Laitière staff often mentioned that if cooperatives were unable to deliver high-quality milk, the agro-industry would increasingly rely on individual large-scale dairy farms. As described by Simonoskova and Nilsson (2011), the risk is that small-scale farmers and milk collection cooperatives are progressively excluded from the formal value chains and thus obliged to sell their milk at lower prices to informal dairy chains whose milk processing capacities are much smaller. These limited results stand in contrast with those of dairy cooperatives in Europe at the end of the $19^{\text {th }}$ century. At that period, dairy cooperatives were able to impose quality control to prevent skimming because the cooperatives also processed the milk and made the butter themselves. They knew the benefits to be had from improving milk quality and were able to design quality-based payments accordingly (Henriksen and Hviid, 2004). This was not the case in the dairy chain in Casablanca. 


\section{Power asymmetry between cooperatives and the agro-industry}

The previous section clarified how external actors influenced the capacity of cooperatives to improve quality management, and how these actors in fact limited this capacity with respect to almost all the tests. Cooperatives had already sent complaints about these issues, but Centrale Laitière did not respond to their queries. As in Singh (2002), its strong power vis-à-vis the cooperatives was mostly due the fact that it enjoyed almost complete monopsony. However, this hard stand reduced the farmers' willingness to improve milk quality ( $\mathrm{Wu}, 2006)$ and many farmers continued to skim their milk.

There are several possible ways to support cooperatives when dealing with other actors of the value chain. First, cooperatives could form federations, which would have a stronger position in negotiations with the dairy processing company. These negotiations could focus on decreasing the asymmetry of information concerning quality as measured by Centrale Laitière, or on designing and monitoring an independent "third-party" laboratory in charge of measuring quality. This laboratory could be run with the support of the state administration (Hueth and Ligon, 2003). Another more drastic option would be for the cooperatives to deliver to a different dairy processing company. At the time of the study, a group of cooperatives in the region of Casablanca, including one of the cooperatives in this study, had already contacted another company operating in another region (which was actually a cooperative) to start collecting their milk.

\section{Conclusion}

The four cooperatives studied here innovated by developing a quality management system based on RAMAs, not as a one-off strategy with the installation of the RAMAs, but in a dynamic way, particularly depending on the development of their relations with the other actors of the value chain. Quality management based on the use of RAMAs involved a wide range of actors, far beyond a simple technical procedure aimed at eliminating 'free-riding' behavior. Cooperatives had to look both inward and outward to succeed in implementing their quality management systems.

Nevertheless, the cooperatives did not succeed in completely preventing farmers from skimming their milk. The capacity of cooperatives to implement quality management was constrained by the complex interactions between farmers, cooperatives, competitors for milk collection, and the agro-industry.

We do not conclude that internal governance is of secondary importance. On the contrary, the failure of collective action in $\mathrm{C} 1$ or the fact the cooperative $\mathrm{C} 2$ was run as a private business by its president underlines the importance of improving cooperative governance. But our analysis demonstrates that the external environment of a cooperative can prevent it being the key coordinator between farmers and agricultural value chains in achieving high quality. This was especially clear in the case of C3 and C4. The introduction of RAMAs was indeed an important "card" in the hands of the cooperatives, but some of the cards the cooperatives needed to achieve quality management were missing from the pack.

The analysis reported here shows that studies on how cooperatives can meet the increasing quality challenge should not be limited to governance and management issues at the cooperative level, which would take the whole supply chain as a given. Future studies should consider the other members of the supply chain as fully-fledged actors, whose strategies can seriously affect the room for maneuver cooperatives have when drawing up new agreements with their members for improved quality management.

\section{Notes}

1. In May 2012, the Moroccan Dirham (DH) was valued $1 \mathrm{DH}=0.09 €$.

2. See www.ekomilk.eu. 


\section{References}

Berdegué, J. (2001) Cooperating to compete. Peasant associative business firms in Chile. PhD thesis, Wageningen University, Wageningen, The Netherlands.

Bijman, J., and Wollni, M. (2009) Producer Organisations and Vertical Coordination. An Economic Organization Theory Perspective. In: H.J. Rösner and F. Schulz-Nieswandt (eds), Beiträge der Genossenschaftlichen Selbsthilfe zur Wirtschaftlichen und Sozialen Entwicklung. Berlin: LIT- Verlag, pp. 231- 252.

Bijman, J. (2008) Contract Farming in Developing Countries: An overview. Working Paper, Wageningen University, the Netherlands.

Bogetoft, P., and Olesen, H.B. (2002) Ten rules of thumb in contract design: lessons from Danish agriculture. European Review of Agricultural Economics 29(2): 185-204.

Boland, M., and Marsh, T.L. (2006) Input quality in the sugar beet industry. Journal of Agricultural and Resource Economics 31(1).

Borgen, S.O. (2011) Product differentiation and cooperative governance. The Journal of SocioEconomics 40(3): 327-333.

Bowonder, B., Raghu Prasad, B. R., and Kotla, A. (2005) ICT application in a dairy industry: the eexperience of Amul. International Journal of Services Technology and Management 6(3): 241-265.

Capitello, R., and Agnoli, L. (2009) Development of strategic options for Italian wine cooperatives through a new membership integration pattern. Paper presented at the $113^{\text {th }}$ Seminar of the European Association of Agricultural Economists; 3-6 September, Chania, Greece.

Cechin, A., Bijman, J., Pascucci, S., and Omta, O. (2013a) Decomposing the member relationship in agricultural cooperatives: Implications for commitment. Agribusiness 29 (1): 39-61.

Cechin, A., Bijman, J., Pascucci, S., Zylbersztajn, D., and Omta, O. ( 2013b) Quality in cooperatives versus investor-owned firms: Evidence from broiler production in Paraná, Brazil. Managerial and Decision Economics 34: 230-243.

Chaddad, F.R., and Boland, B. (2009) Strategy-structure alignment in the world coffee industry: The case of Cooxupé. Review of Agricultural Economics 31 (3): 653-665.

Cook, M.L. (1995) The future of U.S. agricultural cooperatives: A neo-institutional approach. American Journal of Agricultural Economics (77): 1153-1159.

Coulter, J., Goodland, A., Tallontire, A., and Stringfellow, R. (1999) Marrying farmer cooperation and contract farming for service provision in a liberalising sub-Saharan Africa. Natural Resource Perspectives 48.

Draaiyer, J., Dugdill, B., Bennett, A., and Mounsey, J. (2009) Milk Testing and Payment Systems. Resource book. Rome: FAO.

Dries, L., and Swinnen, J. F. (2004) Foreign direct investment, vertical integration, and local suppliers: evidence from the Polish dairy sector. World Development 32(9): 1525-1544.

Francesconi, G.N. (2009) Cooperation for competition. Linking Ethiopian farmers to markets. PhD thesis, Wageningen University, Wageningen, Netherlands.

Fulton, M.E., and Sanderson, K. (2003) Co-operatives and farmers in the new agriculture. Report No. 31780, Centre for the Study of Co-operatives, University of Saskatchewan, Canada.

Gorton, M., Dumitrashko, M., and White, J. (2006) Overcoming supply chain failure in the agri-food sector: A case study from Moldova. Food Policy 31(1): 90-103.

Hanf, J. H., and Schweickert, E. (2012) Power play in the German wine business: Are German wine co-operatives able to use their power to manage their business relationships? Journal of Economics and Behavioral Studies 4(4): 227-238.

Henriksen, I., Hviid, M. (2004). Contracts in the governance of the early Danish dairy sector. Report, University of East Anglia, UK.

Henson, S., Masakure, O., and Boselie, D. (2005) Private food safety and quality standards for fresh produce exporters: the case of Hortico Agrisystems, Zimbabwe. Food Policy 30 (4): 371-384.

Henson, S., and Reardon, T. (2005) Private agri-food standards: Implications for food policy and the agri-food system. Food Policy 30(3): 241-253. 
Hueth, B., and Ligon, E. (2003) On the efficacy of contractual provisions for processing tomatoes. Paper presented at the annual meeting of the American Agricultural Economics Association; July 2730, Montreal, Canada.

Humphrey, J. (2006) Policy implications of trends in agribusiness value chains. The European Journal of Development Research 18(4): 572-592.

Hviid, M. (2006) Performance-related pay in Danish cooperative creameries. Advances in the Economic Analysis of Participatory and Labor-Managed Firms (9): 149-176.

Kaganzi, E., Ferris, S., Barham, J., Abenakyo, A., Sanginga, P., and Njuki, J. (2009) Sustaining linkages to high value markets through collective action in Uganda. Food Policy 34(1): 23-30.

Li, T.M. (2011) Rendering Society Technical: Government through Community and the Ethnographic Turn at the World Bank in Indonesia. In D. Mosse (ed) Adventures in Aidland: The Anthropology of Professionals in International Development. Berghahn Books: New York, pp. 57-79.

Mahdi, S. (2012) Quality Contingent Contracts: Evidence from Tanzania's Coffee Market. World Bank Policy Research Working Paper $n^{\circ}$ 6171.Washington, DC: World Bank.

Mather, C., and S. Greenberg (2003) Market liberalisation in post-apartheid South Africa: the restructuring of citrus exports after deregulation. Journal of Southern African Studies, 29(2): 393-412.

Milktronic (2013) Lactoscan SA Milk Analyzer Operation Manual. http://www.lactoscan.com/pdfs/Lactoscan_SA_Eng.pdf, accessed April 2013.

Narrod, C., Roy, D., Okello, J., Avendaño, B., Rich, K., and Thorat, A. (2009) Public-private partnerships and collective action in high value fruit and vegetable supply chains. Food Policy 34(1): 8-15.

Nilsson, J. (1998) The emergence of new organizational models for agricultural cooperatives. Swedish Journal of agricultural research 28(1): 39-47.

Nyoro, J.K., and Ngugi, I.K. (2007) A qualitative analysis of success and failure factors of agricultural cooperatives in Central Kenya. In: Barrett, C.B., Mude, A.G., and Omiti, G.M. (eds.) Decentralization and the Social Economics of Development - Lessons from Kenya. Cabi: Wallingford, UK, pp. 13-22.

Pennerstorfer, D., and Weiss C.R. (2012). Product quality in the agri-food chain: do cooperatives offer high-quality wine? European Review of Agricultural Economics 40(1): 143-162.

Ponte, S., and Gibbon, P. (2005) Quality standards, conventions and the governance of global value chains. Economy and society 34(1): 1-31.

Prowse, M. (2012) Contract Farming in Developing Countries: a Review. Paris: Agence Française de Développement.

Reardon, T., Barrett, C. B., Berdegué, J. A., and Swinnen, J. F. (2009) Agrifood industry transformation and small farmers in developing countries. World Development 37(11): 1717-1727.

Rourke. K.H. (2007) Culture, conflict and cooperation: Irish dairying before the Great War. The Economic Journal 117: 1357-1379.

Simonovska, A., and Nilsson, J. (2011) Conditions for structural change in the Macedonian dairy industry-the dairy farmers' choice of processors. Post-Communist Economies 23(4): 539-551.

Singh, S. (2002) Contracting out solutions: Political economy of contract farming in the Indian Punjab. World Development 30(9): 1621-1638.

Sraïri, M.T., Benhouda, H., Kuper, M., and Le Gal, P.Y. (2009) Effect of cattle management practices on farms operating in a two stage dairy chain. Tropical Animal Health and Production 41: 259-272.

Sraïri, M.T. (2011) Dairy Development in Morocco. Rome: FAO.

Theodorakopoulou, I., and Iliopoulos, C. (2012) Support for Farmers' Cooperatives; Sector Report Wine. Wageningen: Wageningen UR.

Touzard, J.M. (2010) Ancrage Territorial et Construction de Règles dans une Organisation. In : J. Muchnick J. and C. De Sainte Marie (eds) Le Temps de s SYAL. QUAE Editors: Versailles, France, pp. 265-279.

Touzard, J.M., Gaullier, C., and Jarrige, F. (2001) Qualité du vin et prix du raisin. Trois lectures du changement dans les coopératives de Languedoc. Étude de recherche sur les systèmes agraires et le développement 32, 19-35.

World Bank (2007) Agriculture for Development. World Development Report 2008. Washington, DC: World Bank. 
Wu, S.Y. (2006) Contract theory and agricultural policy analysis: A discussion and survey of recent developments. Australian Journal of Agricultural and Resource Economics 50(4): 490-509. 